\title{
Human Rights Violation and Persecution of Rohingya Muslims in Myanmar
}

\author{
Safdar Ali \\ Ph.D Reserach Scholar \\ Department of International Relations \\ Shah Abdul Latif University Khairpur, Sindh \\ Fatima Ali \\ Lecturer \\ Department of History \& Pakistan Studies \\ The Women University Multan \\ Muhammad Atif \\ PhD Scholar \\ Institute of Social Sciences \\ Bahauddin Zakariya University Multan
}

\begin{abstract}
:
The Rohingya Muslims are living as the minority in Myanmar from a long time. Yet, they always faced discriminatory behaviour of Buddhist majority community and the government. The violation activities against minorities at sectarian basis continued from a long time but currently increased a lot. As a result, thousands of Rohingya refugees migrated towards other areas to protect their lives especially in Bangladesh. The proposed research is an attempt to investigate the real causes and consequences about Rohingya crises in Myanmar. The Rohingya ethnic cleansing mission started after the attack of the Arakan Rohingya Salvation Army (ARSA) on the military of Myanmar. For the analysis of Human rights violation has been used deductive and qualitative research method through which find out the role of internal power of Myanmar and the international leaders and institutions to stop violence against Rohingya Muslims and the their ethnic cleansing.
\end{abstract}

Keywords: Mynamar, Muslims, human rights, violence, India

\section{Introduction:}

The new states are searching for a national identity and domestic coherence. While the stratification within the communities throughout South and Southeast Asia cut across and largely ignore political frontiers, the outstanding cleavage between the several ethnic groups is to be found in the multinational state of Myanmar. ${ }^{1}$ Ever since independence, triton has faced the problem of 'assimilation' of 'Burman' nationalism of the Buddhist order. An attempt has been made by the present writer to examine the condition of Burmese Muslims, particularly of the Arakan (which adjoins Bangladesh), who have been subjected to a great deal of difficulties, especially of a discriminatory nature. In recent years, it has been wrongly alleged that they are foreigners, and under this plea they were pushed across the border. Because of brutal attitude, the Rohingya Muslims refuse to leave the country, as they assert 
that they are Burmese citizens and have no other country to go to. The Economist of London wrote: "Yet it is Asia which has produced this year's biggest and strangest refugee movements. The biggest single groups are the 170,000 Rohingyas, the Muslim Bengali people from the Arakan region of Burma, who are still stream out of it across the Naaf River into Bangladesh at a rate of about 2,000 a day. There seems little doubt that they were harried out of Burma by the Burmese Army and their Buddhist neighbours, although the Burmese insist that only illegal immigrants uncovered through a census check, were 'asked to leave'. ${ }^{2}$ It further observed that any refugee who selects impoverished and authoritarian Bangladesh asa sanctuary to flee to must be desperate indeed. More than 150,000 Muslim Rohingyas, who have farmed alongside Buddhists in the Arakan province of Western Burma for generations are apparently that desperate. ${ }^{3}$

\section{An Historical View of Myanmar:}

Myanmar is also known as the Burma called a Socialist Republic has a population of more than five million, occupying an area of over 26,000 square miles. Myanmar is a neighbour of Bangladesh and India (in the west), the People's Republic of China (in the north) and Laos and Thailand (in the east). The Bay of Bengal and the Indian Ocean lie to the south-east and the south-west of Myanmar (former Burma) respectively. The country as a whole is cut off by mountain barriers from its neighbours. It was geographically part of Indochina rather than of India and was indeed long known to the French as Indochina Anglicize. ${ }^{4}$ The present inhabitants of Burma (excluding the Arakan) are descendants of various Mongolian tribes which migrated southwards into the basin of the Irrawaddy River in remote times. More than 2,000 years ago the people accepted Buddhism, and since that time its monastic system had dominated the life of the country.

Parliamentary democracy in Myanmar became discredited in spite of the charisma of Prime Minister $\mathrm{UNu}$ and in 1958, the army seized power. Temporarily, the reins of government were transferred to the politicians only to be taken back again in March 1962. In fact, the Burmese Army has been in political ascendancy, in one form or another, since the Japanese War. General Ne Win took over control of the government on 2 March 1962.

The first major step the Government took was the Enterprise Nationalization Law of February 1963, a comprehensive measure authorizing wide-scale nationalization of industries. In fact, Ne Win's Government nationalized almost all private and especially foreign enterprise. Even educational institutions were nationalized, without compensation to 
the owners. The government of General Ne Win faced the persistent opposition of ethnic minorities. The minorities demand an autonomous position for their respective regions under the rule of the majority (Buddhist) who has continued to repress the minorities' traditions and cultures.

The geographical peculiarities of Arakan have influenced the political, social and economic conditions of the Muslim Rohingyas and the Buddhist of Arakan. The island port of Akyab and the riverine port of Maungdaw were developed by the Arakanese. The relations between the two communities, the Rohingyeas and Maghs remained harmonious, till the alleged killing of 80,000 Rohingyas by the 'nationalist' Buddhists in 1942. The isolation of the Arakan region from the rest of Burma and its cultural affinity with Bengal, the Japanese occupation of Burma (1942-1945), and the British war time promises of semi-autonomy, encouraged a kind of Arakanese nationalism. In 1946, the Northern Arakan Muslim League was formed in Akyab, which demanded union with Muslims across the border. Before the independence of Pakistan and Burma, the Muslim leaders, particularly those from Bengal, seemed to be mildly inclined towards the Arakanese Muslims' demand. But in 1947, the President of the All-India Muslim League Mohammad Ali Jinnah, asked the Muslims of Arakan to identify themselves with the Burmese, and advised them to settle amicably their grievances, if any, with their countrymen. In spite of this categorical statement of the Founder of Pakistan, which the successive Pakistani Governments, for their part, faithfully adhered to, Burmese leaders were not quite convinced of Pakistan's non-involvement in the Mujahid separatist movement of the Arakan region. In June 1952, a Treaty of Friendship was signed between Burma and Pakistan. However, the problem of the Arakanese Muslims remained a sore point between Pakistan and Burma, though Pakistan Government always tried to keep the issue within the diplomatic parlor, and showed no interest in fostering a religious war.

\section{Early communal conflicts in Myanmar:}

The Rohingya, an ethnic minority in Myanmar, have long complained of religious and cultural discrimination at the hands of the majority Buddhist people. About $10 \%$ people are those who have no any region or territory for them and live in Myanmar and Rohingyas make up the single largest stateless community in the world.

The most effective section of the Arakanese Muslims, soon after Myanmar (former Burma) independence, was the Independent Arakanese Parliamentary Group led by Ba 
Myaing and Kyaw Min, the latter was formerly an outstanding member of the Indian Civil Service and a Director of the Nation newspaper. This group owed its origin to widespread dis-satisfaction among the Arakanese with the government of the time. ${ }^{5}$ The Arakanese Muslims were amongst the first Burmese to realize the power of western education. They were outstanding in the Burmese banking and the civil services and they produced some of the most able public men of the diarchy days of the British Raj. The unrest and confusion in the Arakan region obliged 5,000 non-political fugitives to escape to East Pakistan by 1949.

The Provincial Government of East Pakistan obtained help from the Centre for their rehabilitation. In January 1950, after serious communal strife in Burma, another 30,000 Muslims, mostly from the Arakan, migrated to Pakistan. ${ }^{6}$ The communal riots broke out on 13 November 1961 at a place eight miles north of Rangoon. Some Buddhist monks had occupied a site intended for the construction of a mosque. Led by the monks, the mob destroyed two other mosques, and looted houses and shops in the area. As a result, four persons were killed and thirteen injured. ${ }^{7}$ Another significant event, and perhaps, the last act of the $\mathrm{U} \mathrm{Nu}$ Government, was a Constitution (Amendment) Bill to create an Arakan state, which was scheduled to be introduced in the Parliament on the first of March 1962. However, this was withdrawn at the last minute from the agenda. ${ }^{8}$

In 1967, once again, there were reports of ill-treatment of the Rohingya Muslims. The Government of Pakistan tried to discourage the publicity of these reports for the sake of Pakistan-Burma amity; nevertheless the President Ayub was very much perturbed, and even sent a thinly veiled warning to the Burmese Government by saying that I hope you do not want our forces to cross the border. In 1968, the Pakistan Government revealed that there were 109 Myanmar families in East Pakistan and in 1971A.D, the Pakistan Embassy at Rangoon deputed an officer to check the nationality of the persons living on the PakistanBurma border. However, with the breakup of Pakistan and the emergence of the new state of Bangladesh in Pakistan's eastern wing, the problem of Burmese Muslims was inherited by the Government of Bangladesh. In 1970s, thousands of Rohingya Muslims came along the Arakan border. During this period, Burma faced a most serious problem of law and order, for there were riots by workers and students. It was reported at that time that hundreds of Burmese Muslims were coming as refugees to Bangladesh.

The Bangladeshi leaders focused on the Rohingya refugees and made an appeal to the United Nations to solve this great ethnic problem. In 1975, the Government of General Ne 
Win adopted a new Constitution, purportedly made by the people for safeguarding their interest. ${ }^{9}$ Ironically, this brought more misfortune for the Muslims of Burma and for a time about 500 Muslims came across the border daily as refugees to Bangladesh. So, the President Ziaur Rahman of Bangladesh during a visit of Rangoon brought these facts to the notice of Burmese leaders. In 1978, the Burmese Government policy of "Operation Dragon King" (Project Naga Muri) was put into operation, which was regarded as the ethnic cleansing of Rohingya Muslim of the Arakan province. ${ }^{10}$ However, the Burmese Department of Immigration and Manpower claimed that this policy was simply to examine the illegal entry of Bengali immigrants to Burma. On $30^{\text {th }}$ April 1978, the Ne Win Government issued a lengthy but unsatisfactory statement in connection with the mass exodus of Arakanese Muslims into Bangladesh, and described the policy as a routine immigration check in the border areas. The number of Rohingya Muslims who fled to Bangladesh from March to May 1978 seemed to be over one hundred thousand. The Bangkok Post and the world press carried detailed reports of the refugees and published a number of photographs showing streams of evicted men and women carrying children on their shoulders in the deep mud of the River Naaf. The refugees were victims of torture, looting, arson, rape, and were even evicted by the Burmese troops at gunpoint. ${ }^{11}$ With the passage of time, thousands of Rohingya Muslims migrated towards border areas of neighbouring countries of Myanmar. So, the Bengali governmentnegotiated with Rangoon quietly since the arrival of the refugees in Bangladesh but the scope of the issue was widening.

The Myanmar Government agreed to settle the ethnic issues and for the repatriation, that would be in three phases; the first phase of the repatriation would cover those who presented Myanmar National Registration Cards and Foreigners' Registration documents. The remaining two phases would cover those who were able to produce documents issued in Myanmar indicating previous residence in the country. The present immigration problem arose not because of any religious or social discrimination, but because of the instigation of unsavoury elements, who were against the collection of data being carried out for the purpose of implementing the socialist system. ${ }^{12}$ In 1970s, more than 6,000 refugees were to be repatriated, but by then only 195 had returned to their homes. However, the United Nations' officials later disclosed that more than 5,000 of the Muslims who had fled to Bangladesh repatriated. 
Chief Field Coordinator for the UN High Commissioner for Refugees (UNHCR) in Bangladesh said that the refugees were moving back to Burma faster than the 2,000 every day stipulated in the agreement. But 190,000 Muslims refugees were still in 13 improvised camps set up by the Bangladesh Government. The refugees' initial suspicions about their safety in Myanmar had been substantially relieved by reports from those who had returned. However, the Myanmar higher authorities considered geographically, the purpose of the political organization of a state is to establish coherent unity and a certain degree of homogeneity over areas which without the state organization are more or less separate and heterogeneous.

During last decade, the communal conflicts among the Rohingya Muslims and the Buddhist community of Myanmar have been much increased. The Rohingya militant group's attack on the security forces of Myanmar, in which died some soldiers, increased the ethnic and communal strife. In return, the operation against Rohingya Muslims started by the military and killed hundreds of Muslims as well as many people harassed, expelled and their houses burned brutally. As a result, almost 87,000 Rohingya Muslims migrated towards Bangladesh but its government not ready to accept them and intended to return them to the Myanmar. ${ }^{13}$ Later on, more than fifty thousand Rohingya refugees crossed the border and are living in the refugee camps on Bangladesh border. In communal strife, around 1000 people are reported to have died in Myanmar's Rakhine state after Rohingya insurgents attacked police posts.

The army says it is conducting clearance operations against extremist terrorists in response to the attacks on police posts. But Rohingya allege that security forces are indulging in arson and killings to force them to flee. The plight of the ethnic minority group has drawn international criticism, especially peace laureate Aung San Suu Kyi. She has been accused of not speaking out for the persecuted minority. UN Secretary General Antonio Guterres urged restraint and calm to avoid a humanitarian catastrophe.

\section{Image of Rohingya Muslims in Myanmar:}

The Myanmar is a state of different ethnic groups but the Buddhist religious identity more dominated as compare to other nations and groups. The Rohingya is also included in the minorities of Myanmar, inhabited in the Rakhine State. They are living in this region from a long time but still not considered lawful by the government of Myanmar. Its people argued that the Rohingya came in this region during British colonial period as the labour but now are living illegally and should go back to their homeland. 
The National identity in the country has been tangled with the official religion of Buddhism and it had a particular importance in the issue of Rohingya. The war on terror against Muslims started at the world level, has paved a way for the government and military of Myanmar to label the Rohingya Muslims as the terrorists. They legitimized the violence against Rohingya ethnic community and expelled them from Myanmar. The Buddhist people are keeping faith that the Muslims and their religion always remained a threat for the Buddhism, Myanmar's majority religion. It has also allowed political and religious elites to unfairly and inaccurately associate all Rohingya with terrorism. They admired to anti-Muslim ideas spread through social media sites, the popular press and the writings and sermons of influential laypeople and monks, Myanmar's citizens have come to see the real picture of Muslims. ${ }^{14}$

The brutality of Myanmar government against the Muslims of Rakhine state has been tried to expose by different researchers, reporters and the investigators as Zeid Ra'ad Al Hussein (UN High Commissioner for Human Rights), who provided evidences of the Myanmar military activities about ethnic cleansing of the Rohingya Muslims. Yet, the government of Myanmar is claiming that there is no any proof of systemic violence against Rohingya and it also not permitting the foreign visitors to come and collect real evidences about ethnic issues.However, the report of the UN High Commissioner for Human Rights prepared after the interview of refugees both men and women, explained the facts about gang rape and harassment of women, mass killings of men, child and women, ethnic cleansing and brutal beatings. In other reports of violence against Rohingyas have been given the detail view of harsh and brutal acts of Myanmar military at the initiative of government as well as highlighted that the security forces forcefully expel the Rohingya Muslims from Myanmar.

\section{Rohingya Muslims as second class citizens:}

The Rohingya Muslims in Myanmar always treated as the second class citizens because of they belong to different language, ethnicity and the religion. Moreover, the Buddhist nationalists of Myanmar have the feelings of fear and insecurity about their culture and traditions which is losing its uniqueness as the Burmese (Buddhist). They think that native traditions of the Buddhist are highly influencing by the cultural and communal amalgamation of other communities like Rohingya, Chinese and others. It is an alarming situation for the pure Buddhist and the native people of Myanmar because it may possible that in future any other community dominated in their own country and they lived as the subjects of dominated class. 
The Rohingya are considered as the prime example of foreign culture and social invasion. So, the Myanmar rigid people and government are trying to suppress them and mold according to their own system and social patterns.In the schools of Rakhine state has been implemented the teaching of Buddhism and its culture as well. Thus, the government of Myanmar is anxious about their own socio-cultural patterns and religious norms and intended to expel the non-Buddhist communities from Myanmar. The Rohingya refuges are the main examples, lived at the border of Bangladesh as the non-state people, aided by the UNO, Red Cross and other social welfare and Human rights organization of the world.According to the estimated report of UNHCR, there are a huge number of state less people around the world (almost 10 million) including Rohingya Muslims. ${ }^{15}$ The international Organizations including UNO are making serious attempts for the proper settlement and equal citizenship rights, opportunities in every sphere of life of the state less people especially for the Rohingya.

On the other side, the government of Myanmar is ready to support them not as its own citizens but as the migrated people of Bangladesh. The Buddhist argued that the Rohingya are not keeping birth relations with this state but came in the past from Bangladesh and other regions just for their own work and jobs. In the report of Rakhine Advisory commission which held under the supervision of Kofi Annan, (UN Secretary General), said that the issue of Rakhine state is just related to the matter of citizenship because the native population of Myanmar not ready to accept them as their own citizens. If it not solved timely then may cause the human sufferings, insecurity and socio-economic troubles. There is a core need of clear strategy to stop human rights violation and revision of the citizen rights law of 1982 made by the government of Myanmar.

\section{Violence (hidden genocide) against Rohingya:}

The Myanmar is keeping heterogeneous society consisted on more than one hundred and thirty five ethnic groups called minorities. The status of minorities not accepted by the Buddhist majority and its government, moreover, they are also not giving them their social rights as the citizens of Myanmar. The hidden and open genocide of the minorities in Myanmar is continued from a long time and thousands of people including Rohingya forcefully migrated towards other areas of the world, where they are deprived of the social needs, proper education, food, health, and economic assistances. They are also have no any state identity and working as the slaves on fishing boats in Southeast Asia.

Currently the democratic transit government established under the NLD political party also associated with the fundamentalist Buddhist people and the military and Aung Suu Kyi (councilor of NLD) is neglecting the issue of Rohingya Muslims genocide in the Rakhine 
state through the forces of Myanmar. In other words, it can say that Myanmar stands on the brink of genocide. ${ }^{16}$

The ethnic conflicts history is so long, in Myanmar started after its establishment and still enduring. There has been given some examples of ethnic conflicts of Myanmar between Muslims and the Buddhist community as in 2012, almost 200,000 people migrated towardsBangladesh, Malaysia, Thailand and Indonesia to secure their lives. Later on, many operations held against the minorities especially the Rohingya Muslims and the military operations involved arbitrary killings, harassment, rapes, genocide, the burning of houses and forced expulsions of the natives. As a result of violence activities in last months of 2016, about 500000 people fled to the border areas of Bangladesh, where they are facing multinature hardships of survival. Currently, the exodus of Rohingya Muslims is continuing because of the brutal crackdown of government following attacks by Rohingya armed group. However, the international organizations and the state actors tried their best to stop the violence activities of Myanmar and clear that it can be harmful for the peace and stability of Southeast Asia.

On $25^{\text {th }}$ August 2017, serious violence broke out again in the Rakhine state when hundred Muslim armed men attacked on the security forces of Myanmar and killed some soldiers. In the reaction of it, the hostile and brutal steps have taken by the forces and killed hundreds of people, burn their houses, the women harassed and raped as well as the children too killed harshly. It was one of the worst sectarian violence has forced thousands of people to leave the Myanmar forever. So, a mass migration held and 60,000 more people entered in Bangladesh during the conflicts. ${ }^{17}$

However, the government of Myanmar especially noble peace award holder Aung San Suu Kyi and other fundamentalists are not accepting the responsibility of all these brutal ethnic or sectarian violence activities. They claimed that as per accusation, there is no possibility of crimes and violence against humanity and ethnic cleansing in Myanmar.The outer world is fabricating genocide and ethnic cleansing false stories about Myanmar. During the discussion of Aung San Suu Kyi with Turkish President Recep Tayyip Erdogan, she insisted on the same words and not accepted any accusation against Myanmar. ${ }^{18}$ 


\section{Bangladesh Authorities step for Refugees:}

The government of Bangladesh is keeping deep interest to solve the problems of migrated people because it has not much sources and land to settle all refugees in its boundaries.Moreover, it wanted to stop increasing and daily basis migration of thousands of Rohingya Muslims. The refugees are going to other areas including Bangladesh through boats and the land routes but not owned and accepted by other states. The reason is that most of the states not having much sources to provide proper facilities of life to the refugees.

After the sectarian clashes of August 2017, many Rohingya refugees tried to enter in Bangladesh but forcefully returned to Myanmar because of the zero tolerance policy for Rohingya entering in it. Despite of strict measures, thousands of Rohingyas entered in Bangladesh and currently almost 150,000 peopleare living in the refugee camps but in nasty conditions. ${ }^{19}$ However, more and more migrants are trying to enter Bangladesh via the Ghumdhum border area, where the forces of Myanmar are engaged in an operation against armed militias.

The searing violence, some of the deadliest to have hit Myanmar's Rohingya community has forced tens of thousands to flee to neighboring Bangladesh. The influx has come despite Bangladeshi authorities toughening border patrols in a bid to prevent more refugees from entering a country that already hosts an estimated 400,000 Rohingya refugees.

The UN Refugee Agency (UNHCR) regional spokeswoman Vivian Tan told that more than 27,000 Rohingya had crossed into Bangladesh in the last week of October. She warned the number was likely to be revised upward.Reuter's news agency reported that around 38,000 people were estimated to have crossed over. It said 20,000 more Rohingya was stuck in a no-man's-land at the border. We are working with the Bangladeshi authorities and our partners provide life-saving assistance, including temporary shelter, food and medical treatment for those who need it," Tan said that the (refugee) camps are swelling fast so there is a need to find additional land to build new shelters and services. Many of the new arrivals were women and children, including heavily pregnant women. They are all exhausted after walking for days to reach Bangladesh, often with no food and just the clothes on their backs. They also seem traumatized by what they have been through. About 1.1 million Muslim Rohingya are currently living in mainly Buddhist Myanmar has been denied citizenship and are classified as illegal immigrants. They are often subjected to violence. ${ }^{20}$

\section{Violent attitude to Rohingya Women:}

The Rohingya Muslim minority has fled repression in Myanmar for generations. In neighboring Bangladesh, refugee camps offer asylum, but life there remains bleak. According 
to the reports of different human rights supportive groups and the institutions, the military committed inhuman crimes and also indulged in the harassment and rape of Rohingya women and in the killing of children.

The men as well as women were highly victimized by the brutal actions of military forces of Myanmar. Through the explanation of some issues related to the violence and harassment against women can properly generalize the inhuman activities and the role of Myanmar as the silence actor.

Afifa is a teenager of fourteen years old girl, who faced the brutality of Myanmar military officers. She with dozens of girls and women were in a rice paddy, the soldiers reached there who invaded her village as well. They were searching for the militants who attacked on their border posts and killed nine policemen. All the village people went towards forests and closed their doors to secure their lives but the soldiers began terrorizing the women and children.

The soldiers came nearer Afifa and gazed her, two young women dragged deep into the rice paddy by the soldiers. One military man insisted Afifa to perform dance and if you don't dance than we will kill you. So, Afifa performed dance because of the fear of military man, who slide his arm around her waist. Later on, went towards other villagers to search the Rohingya militants.

Afifa said that the military men to many houses and the rice fields. Moreover, they robbed the houses and took all precious things as well as shot many cattle and the humans. As a result, the Afifa's family decided to migrate towards refugee camps and left the house to secure their lives and succeeded to reach in Bangladesh after five months long and risky travel as on the first attempt to cross the Naf River (divided Bangladesh and Myanmar) faced the military fire. Finally, one day they reached Balukhail camp and are still living there in the hope of secure return to Myanmar.

Another case is of Rzina Akhtar, twenty two years old lady, lived in the refugee camps. She said that her family came in camps when she was just seven years old child. She and her family members have no any hope to go back in their homes because had no passports, ID cards and any other permission letter. Now, she welcomed all new migrated refugees as her own family through medical care, plastic tarpaulins and food rations. For their economic survival, they do different small scale jobs as fishing, harvesting, rice and many women and child go for begging along the roads. 
Minara is an eighteen years old girl, who lost her family and living alone in the refugee camps. She was victimized of gang rape by the soldiers of Myanmaras well as several other young women in her village. Nur Ayesha says she was burned on her face and arm when the Burmese military torched her house while she was in it. She has received treatment at Kutupalong by the medical visitors.

Another woman named Nurul Aimanvictimized by the brutality of military men.She is living at Kutupalong, a refugee area in Bangladeesh. She was wounded by the multiple times shooting of soldiers in her arm, which had to be removed by the doctor.

Molia Banu is now sixty years old lady who was victimized by the military soldiers. She lived in refugee camp with her daughter, who fled from Rakhine when the military began burning a house next to theirs. Moreover, they gunned down many women including the pregnant female as well.

Another case is of a lady Yasmin belonged to Ngan Chaung village. She is twenty seven years old and victimized by the brutality of military. The soldiers entered in her home and raped her in front of her five-year-old daughter. She also suppressed and made silence by pointed gun at her.Moreover, her eight years old boy alsokilled by shooting, whowas lying in the rice paddy.

Aung San Suu Kyi has visited northern Rakhine and argued that there is no any activity going on for ethnic cleansing. However, she can't deny the evidences of military attacks on the civilians, villages burning through fire and mass killing, collected by the independent investigators, journalists, or aid groups. The investigators said that there were huge masses of burnt bodies of children and adults lying on the ground.

The Rohingya refugees argued that the government, military and the Buddhist majority community wanted to get rid of the ethnic groups or minorities. However, they are living with the hope to go back at their homes when they accepted as the citizens of Myanmar.

\section{Aung San Suu Kyi and Rohingya crisis:}

During the $20^{\text {th }}$ century, activists struggled to establish a democracy and the Burmese were at times under a strict, militaristic regime. For more than a century, Burma was a British colony, until it declared independence in 1948. The country was briefly a democratic republic, but instability created a power vacuum that was exploited by General U Ne Win, who led a military coup in 1962. By 1974, he had established a regime that isolated the country. 
Further crackdowns on what remained of the country's democratic institutions came in 1988 when the military responded to student-led protests by killing at least 3,000.

The country's ruling military junta changed the name of the state from Burma to Myanmar in 1989, but this change is not officially recognized by the U.S. and UK. (National Geographic refers to the country as Myanmar.) Use of the name Myanmar remains controversial among some, who say it infers support for military rule. In the past five years, Myanmar has become less isolated, and Aung San Suu Kyi's victory represented a step toward democracy for citizens of Myanmar.

The daughter of a resistance movement general, Aung San Suu Kyi has been advocating for a democratic Myanmar for nearly her entire life. She became a leading figure for the National League for Democracy, then an opposition party, in the late 1980s, but she was detained in 1989. She spent 15 years under house arrest, won the Nobel Peace Prize in 1991, and has been hailed as a leader of democracy around the world. However, Aung San Suu Kyi has not publicly condemned the military's treatment of the Rohingya, and this has tarnished her international reputation. Human rights activists believe it's her responsibility to speak out against the military's violent assault, but she has no functional control over the military. During Myanmar's most recent election, the NLD won the majority of the country's parliamentary seats. As the leader of the NLD, Aung San Suu Kyi is Myanmar's de facto leader, officially named its "state counselor but that still doesn't mean Aung San Suu Kyi can rein in her country's military, which had established power years before her election and doesn't have to answer to her. The military is guaranteed the rights to appoint 25 percent of Myanmar's parliamentary seats, giving it veto power over constitutional amendments. As a result, Aung San Suu Kyi and the NLD are barred from moving the military under civilian control.

A year ago, Aung San Suu Kyi's party took over the reins of the country as Myanmar's first elected government in half a century. Things haven't turned for the better for everyone since then. It has been a year since Aung San Suu Kyi's National League for Democracy (NLD) took over power from a military backed regime in Myanmar, a development welcomed by the people with full of hopes and expectations. The de-facto leader Aung San Suu Kyi, officially the state counselor has managed to retain her popularity since taking office. Wherever she appears, all eyes are on her. The democracy icon still enchants all those who approach her. 
The Lady, who sacrificed her family and liberty in the struggle for democracy in her home country, is still regarded as the nation's savior. But things have changed over the past year, as the NLD government has hardly any achievements to show so far.

\section{Challenges of Aung San Suu Kyi:}

On March, 2017, the National League for Democracy took power under the leadership of Aung San Suu Kyi but inherited the ethnic issues of Myanmar. There can elaborate about the main challenges of NLD:

- The issues of mismanagement, sanctions and the economic crises

- Increasing discrimination and social violence between the sectarian minorities and the Buddhist majority.

- The issuance of strong and proper policies to stop the ethnic insurgency in the border states of Myanmar

The issue of Rohingya was regional in its nature which converted in a sectarian and ethnic conflict through which adopted the policy of ethnic cleansing and genocide of the people. So, a serious tension and insecurity developed among the people of Rakhine state and they started migrating to secure themselves. As a result, international human rights protectors came ahead to stop violence against the Muslims of Rakhine but the government of Myanmar is appeared uninterested in all these issues of inhumanity. For the solution of ethnic issues in Myanmar, there is required proper and solid role of international communities and the powers. The economic assistance should have provided to the Myanmar with the promise to solve ethnic disputes and accept Rohingyas as their own citizens. ${ }^{21}$

\section{World view on Aung San Suu Kyi's role against Rohingya:}

Since April 2016, when the international human rights icon Aung San Suu Kyi became first democratic head of Myanmar, activists, journalists, and policymakers around the world have been expressing shock and disappointment at her performance. In addition to raising questions about her leadership on economic and political reforms, which she has largely failed to deliver on, her critics have charged her with turning a blind eye to crimes against humanity committed by the country's military against the Rohingya minority. Former U.S. President Barack Obama's ambassador to the UN Human Rights Council, Keith Harper, accused Aung San Suu Kyi of failing to use her stature to speak up against the atrocities. Others have been more direct and called her an apologist for genocide against Muslims. Such 
harsh judgments on Aung San Suu Kyi's integrity and competence have less to do with her leadership and more to do with the undue expectations the international community has placed on her. Likewise, critics often overemphasize the role of Aung San Suu Kyi's personal traits while minimizing the structural and situational factors that have influenced her decisions. Placed in the context of the country's misunderstood political, historical, and institutional environment, Aung San Suu Kyi is neither the savior she was once assumed to be nor the villain of today's caricatures. ${ }^{22}$

\section{Foreign Commissions \& Rohingya Turmoil:}

In spite of great fact that the Rohingya Muslims in Myanmar are living from a long time, the Buddhists consider them illegal immigrants and treated as the second class citizens. The security services and military institutions of Buddhist are indulged in the ethnic cleansing through killing and burning of houses of Rohingya under the supervision of government authorities.

The international powers and UNOs decided to send the missions inMyanmar to know the real situation of ethnic cleansing issues. However, the government of Myanmar is not gives permission and arranged its own commissions under the authorities of political and other influential heads. The reports of these commissions and the military in August 2017, mentioned that there is any evidence of crimes against humanity, ethnic cleansing, harassment and rape of women and killing against Rohingya in Rakhine State.Furthermore, the army proclaimed that it not indulges in any severe crime except some minor incidents; including one soldier borrowed the bike without permission. On the other side, the government of Myanmar is not ready to accept any interference of international forces except the suggestions for policy making for the progress of the state. The visas were not issued to the fact finding team of UNO, who wanted to come to investigate the human-rights abuses by saying that will not accept thatthe mission could exacerbate divisions between Buddhists and Muslims. Moreover, these missions would have created thegreater hostility between the different communities.Kyaw Zeya (Foreign Affairs Secretary) said that if the foreign commissions wanted to come to search facts about the social and economic as well as political situation then they allowed entering in Myanmar.Yet, domestic commissions and investigation cells of Myanmar are sufficient to uncover the issues related to Rakhine state. ${ }^{23}$

The Human Rights Council of United Nations wanted to send a fact finding mission to ensure full accountability for perpetrators and justice for victims, but Myanmar's government has not ready to take this initiative and said it would only inflame the conflict. 
Moreover, the warning has been given to the United Nation's council that not to interfere in national matters of Myanmar.

\section{Impacts on Regional security:}

Reports about the exchange of firing between the Security Forces of Bangladesh and Burma constituted a threat to the peace of the region. The Bangladesh Advisor on Foreign Affairs had to warn the United Nations and other peace agencies about the dangerous consequences of the expulsion policy of the Myanmar Government and military. The Islamic Council expressed concern over the extermination of Rohingya Muslims and urged the UN to intervene. The Government of Bangladesh and other world powers appealed to the United Nations to provide humanitarian assistance to the displaced persons, who are lodged in camps in Chittagong and the Hill Tracts of Bangladesh bordering Myanmar.

The World Muslim peace building powers sent messages to the UN Secretary-General and calling his attention to this tragic issue. Furthermore, Bangladesh received aid from the UN, the UNICEF, the International Red Cross and other governments and institutions.

In fact, this is not, therefore, just another of Asia's large perennial bouts of shifting misery. It is large enough already to bring crisis to a host country which hangs perilously to survival on an international aid life line of a billion dollars a year. That automatically makes the Rohingya influx a world problem. ${ }^{24}$ The Economist described it as an ejection of humanity; the latest of Asia's refugee problems and its combination of sheer size and suddenness as bad as the exodus from communist Indochina. ${ }^{25}$ The journal expressed the apprehension that unless there was a complete turnabout by the Myanmar Government, less than a handful of the refugees were likely to be allowed to return to their homes. It further warned that the authorities have done nothing to reassure them in the face of threats of communal violence, imprisonment and forced labour. In past, Bangladesh and Myanmar signed an agreement to settle the problem of refugees in Bangladesh. The principle under lining the agreement was that all those refugees who could produce evidence of any kind of their lawful residence in Myanmar would be accepted by the Burmese Government for settlement. Evidence would include all varieties of certificates, tax receipts, educational papers, rent receipts, residential addresses, etc. The agreement also provided for an early 
resumption of negotiations on the demarcation of the land boundary between Bangladesh and Myanmar. However, it vanished and the ethnic cleansing mission is continued as can see current situation of Rohingya Muslims.

\section{Conclusion:}

At the end can conclude that the Rohingya Muslims are living just like a rolling ball which not accepted and welcome by the Myanmar as well as other neighbouring countries. The refugees are forcefully entered in the border areas because of ethnic cleansing mission started by the militant forces of Myanmar. As a result, the Rohingya Muslims moved from their inhabitant place (Rakhine) towards other regions especially Bangladesh. According to the evidences, more than five lac migrated people are living in the refugee camps of Bangladesh but just nominal strength $(32,000)$ is registered. After 1992, thousands of refugees came in Bangladesh but still not registered properly. It can say an apparent attempt to dissuade more Rohingya Muslims from seeking refuge in Bangladesh.In the refugees are including $2 / 3$ children, at the great risk of being forced into child labour, crimes and the sex trade as well. The refugees are packed and smuggled onto ships by the smugglers through secret camps, beating and killed the ones who did not pay excessive smuggling dues. In the camps, the Rohingya refugees are facing many social and economic issues because of scarcity of food, medicines, sources of employment, education and settlement. The reason is that Bangladesh already considered a poor and overpopulated country and shows no enthusiasm for the hosting of Rohingya people.

However, the government of Bangladesh is trying to handle the issue of ethnic conflicts at the international level with the help of United Nation's Human Rights Commission. On the other hand, the government decided to settle the refugees to a remote area (island) in the Bay of Bengal. It is also attempting to keep away the Rohingyas from the main hub (Cox's Bazar) of tourists and return to Myanmar as well. However, the Rohingya refugees are not ready to go back to their homeland. 


\section{References:}

1 R. M. M. "The Situation in Burma: Difficulties of Post-war Reconstruction", The World Today, London, Royal Institute of International Affairs, September 1946, pp. 430-439

2 "A Time of Flight", The Economist, London, 17-23 June 1978, p, 14.

3 Bangladesh and Burma: Another Ejection of Humanity", The Economist, 10-16 June 1978 , p. 77.

4 Dudley Stamp, India, Pakistan, Ceylon and Burma, Methuen \& Company, London, pp. $381-382$

5 Tinker, H. (1967). "Union of Burma: A Study of the First Years of Independence", Royal Institute of International Affairs, Oxford University Press, London, 1967, p. 68.

6 Mahmud Hussain, the Pakistani Deputy Minister of Foreign Affairs and Com- monwealth Relations' statement of 17 January 1950,

7 Asian Recorder, New Delhi, Vol. VII, 1-7 January 1961, p. 4303

8 Asian Recorder, New Delhi, Vol. VII, 1-7 January 1961, p. 4488

9 Raja Segaram Arunugam, "Burma : A Political and Economic Background", Southeast Asian Affairs, 1975, pp. 41-42. Operation Dragon King", Impact International, London, 26 May-8 June 1978, p. 6.

11 The Pakistan Times, Lahore, 8 May 1978.

12 Dawn, Karachi, 12 July 1978.

$13 \mathrm{http}: / / \mathrm{www} . d \mathrm{w} . c 0 \mathrm{~m} / \mathrm{en} /$ bangladesh-forces-back-scores-of-rohingya-despite-myanmarviolence/a-40256566 https://www.foreignaffairs.com/articles/burma-myanmar/2017-11-06/religion-andviolence-myanmar https://news.nationalgeographic.com/2017/09/rohingya-refugee-crisis-myanmar-burma$\mathrm{spd} /$

16 Azeez Ibrahim, “The Rohingya: Inside Myanmar's Hidden Genocide”, https://www.foreignaffairs.com/reviews/capsule-review/2016-08-11/rohingyas-insidemyanmars-hidden-genocide, retrieved on $29^{\text {th }}$ November, 2017

17 Vivian Tan's report under UNHCR, $2^{\text {nd }}$ September, 2017

18 Lynn Kuok, "The Latest Rohingya Crisis" https://www.foreignaffairs.com/articles/burmamyanmar/2017-09-28/while-world-sleeps-myanmar-burns?cid=int-rec\&pgtype=ar, retrived on $28^{\text {th }}$ November 2017 
19 http://www.dw.com/en/rohingya-people-in-myanmar-what-you-need-to-know/a40340067

$20 \mathrm{http} / / \mathrm{www} \cdot \mathrm{dw} . \mathrm{com} / \mathrm{en} / \mathrm{dea}$ th-toll-in-myanmar-violence-surges-to-400-amid-rohingyaexodus-to-bangladesh/a-40332921

21 Aaron L. Connelly, "Growth, Peace, and U.S. Sanctions", https://www.foreignaffairs.com/articles/burma-myanmar/2016-10-20/myanmars-roadahead, retrieved on $28^{\text {th }}$ September 2017

22 https://www.foreignaffairs.com/articles/burma-myanmar/2017-05-19/aung-san-suu-kyistill-myanmars-best-hope

$23 \mathrm{http} / /$ www.dw.com/en/myanmar-to-block-visas-for-un-delegation/a-39486438

24 The Guardian Weekly, London, Vol. 118, 18 June 1978.

25 The Economist, London, 10-16 June, op. cit., 1978, p.77 